\title{
Skriv sykepleiefaglig godt - og bli lest! (2:2)
}

I stedet for å s $\varnothing$ ke oppover i statushierarkiet til

vanskelige ord $b \varnothing r$ vi heller søke nedover til

hverdagsspråket. Da øker vi muligheten for at mottakeren får med seg budskapet.

Jan Storø

Dosent

Fakultet for samfunnsvitenskap, Oslomet - storbyuniversitetet

\begin{tabular}{|l|l|l|}
\hline Undervisning Fagutvikling og forskning Språk Sykepleie \\
\hline
\end{tabular}

\section{Hovedbudskap}

Ønsker du at det du skriver, skal bli lest og forstått av flest mulig? Her får du gode råd om ordvalg, setningsoppbygging og strukturering av teksten. Artikkelen er den andre av to.

I to artikler tar jeg for meg noen utfordringer knyttet til å det skrive sykepleiefaglige artikler. I denne andre artikkelen ser jeg på konkrete skriveutfordringer. I den første tok jeg for meg fagspråk og formidling i denne typen faglitteratur.

\section{Planlegg og forbered teksten}

Tekster konstrueres av språk. Derfor er det nyttig å arbeide med språket. Språket i en tekst består av ord, setninger og avsnitt. En skriver vil ha glede av å bevisstgjøre seg på den funksjonen de har i teksten. 
Ikke alle skrivere har reflektert over disse funksjonene. Det kan være fordi vi ikke er vant til å reflektere over måtene vi bruker språket på. Talespråket har jo den egenskapen at vi bruker det mer intuitivt. Vi snakker «i vei» og opparbeider oss over tid en følelse for språket, for talemåter, for vår egen og andres dialekter og så videre.

Dermed er vi ofte «intuitivt vitende» i mange spørsmål om den muntlige språkføringen - og det fungerer som regel ganske bra. Vi planlegger ikke så ofte det muntlige språket hvordan vi snakker.

Planlagt språkbruk hører mer til i det skriftlige, som når vi skal holde en tale i for eksempel en konfirmasjon. Talen er muntlig, men fordi det er viktig for oss å gi en god tale, kan det være at vi forbereder oss ved å skrive ned hva vi skal si.

Å skrive en artikkel kan dermed ses på som en forberedt språkhandling. Gjennom å tenke over det som skal uttrykkes og være nøye med hvordan vi uttrykker oss, øker vi muligheten for at mottakeren får med seg budskapet.

\section{Ordene - velg dem med omhu}

Ordene er den minste meningsbærende enheten. La oss se etter gode ordregler. For min egen del fors $\varnothing$ ker jeg å velge forståelige ord fremfor vanskelig tilgjengelige ord.

Dette valget innebærer at jeg følger et ideal om ikke å søke oppover i statushierarkiet - der de vanskelige og spesialiserte ordene befinner seg-, men heller søke nedover til hverdagsspråket - de gangene det er mulig å gå dit. Det er selvfølgelig ikke alltid mulig, eller ønskelig, å legge fra seg et spesialisert språk.

\section{$\equiv$ «For min egen del forsøker jeg å velge forståelige ord fremfor vanskelig tilgjengelige ord.»}

Men de gangene det er mulig, bør vi etter mitt skjønn gjøre det. Noen ganger kan det for eksempel passe å skrive «Man kan bli syk av å røyke», fremfor «Røyking er sykdomsfremkallende». Smak på de to setningene. Hvis det vi vil si, kommer godt frem i den enklere formen i den første av dem, bør denne velges fordi den er lettest å lese. 


\section{Verbene har en viktig funksjon}

La oss se på verbene. De har en viktig jobb å gjøre i

setningene. De forteller frem handlingen. Dette at noe foregår i en setning, er viktig. Det gir hver eneste setning en fortelling. Selv enkle setninger som «Far hører på musikk» og «Mor leser» gir leseren et bilde av at noe foregår. Derfor har verbet en viktig formidlingsjobb å gjøre - i hver eneste setning.

Noen verb er ikke så enkle å lese. Det er de passive verbene. Derfor er det bedre å bruke aktive verb. Aktive verb er tydelig handlingsmettede ord. De har som funksjon i setningen å fortelle om hva som gjøres. Dessuten gir de oss god hjelp til raskt å få øye på hvem som utfører handlingen.

Hvis de gjøres passive, mister de noe av denne funksjonen. Derfor er «Birte ledet møtet» bedre enn «Møtet ble ledet av Birte». Et annet eksempel: «Rapporten skrives av vaktansvarlig før klokka tre» er mer uklar enn «Vaktansvarlig skriver rapporten før klokka tre».

Og, hvis vi går tilbake til eksemplene fra forrige avsnitt: «Musikken blir lyttet til av far» eller «Boka blir lest av mor» er tunge og dermed lite kommunikative.

Vi ser også at setningens subjekt (i dette tilfellet personene Birte, vaktansvarlig, far og mor) fremtrer tydeligere i setningene med aktive verb. Fagskrivere og skrivere av byråkratiske tekster kan oppnå større leservennlighet hvis de følger dette rådet.

Et tydelig subjekt koplet til en tydelig handling ved a bruke aktive verb er gode idealer for skrivingen. Nedenfor har jeg diktet en formulering som er håpløst vanskelig å lese, og deretter foreslått en annen skrivemåte:

Medisinsk grunnkompetanse og postoperativ støttebehandling er det en høy prosent av helseregionene som svarer det trengs forsterket innsats på.

En høy prosent av helseregionene svarer at det trengs forsterket innsats på medisinsk grunnkompetanse og postoperativ støttebehandling. 
På liknende måte kan også andre vanskelige formuleringer gjøre lesingen tyngre. En setning som «Jeg inntok en kritisk holdning til forslaget» er mindre personlig og mer tilslørende enn «Jeg var kritisk til forslaget». Setningsleddet «å innta en holdning» er ikke nødvendig her.

På den annen side er det heller ikke feil å bruke det, der det passer. Men det forvansker gjerne teksten og gjør kommunikasjonen med leseren litt tyngre.

Det finnes mange slike forvanskende ledd. Noen av de vanligste er $i$ forhold til og på bakgrunn av. Hvis vi som skrivere $\varnothing$ nsker å kommunisere best mulig, er disse gode eksempler på hva vi bør se etter i egne tekster og vurdere å styrke.

\section{Substantivsyken er utbredt}

Kittilsen (1) peker på at det som ofte kalles substantivsyken, er et utbredt fenomen i medisinsk språk. Begrepet viser til en tendens til å gjøre om verb til substantiv, for eksempel slik: «Pasienten var gjenstand for en unders $\varnothing$ kelse.»

Her vil det være enklere, mer lettlest og like informativt å skrive «pasienten ble unders $\varnothing \mathrm{k} t$ ». Det sentrale ordet bør få være et verb (unders $\varnothing \mathrm{ke}$ ) fremfor å bli tvunget inn i en substantivform (unders $\varnothing$ kelse). Det samme gjenspeiles $i$ «jeg foretok en unders $\varnothing$ kelse» versus «jeg unders $\varnothing k t e »$.

I begge tilfellene er den korteste setningen lettest å lese. I det første eksempelet inneholder den lengste et annet problem; pasienten blir mer et objekt, en gjenstand, i denne formuleringen.

\section{三 «anskje vi skal stikke hull på denne språklige verkebyllen og kalle en spade for en spade?»}

Substantivsyken er utbredt. Den har antakelig spesielt gode levekår i fagskriving, vitenskapelig skriving og byråkratisk skriving. Det har å gjøre med at vanskelige formuleringer gjerne får en lød av å være betydningsfulle - og dermed fremstår de som uangripelige.

Kanskje vi skal stikke hull på denne språklige verkebyllen og kalle en spade for en spade? Slike formuleringer er ofte uttrykk for jåleri. Klarspråk.no sin Svadagenerator for Helseadministrativ svada gir et bilde av dette (2). 


\section{Vær bevisst på valg av adverb}

En annen ordtype som er viktig i mange setninger, er adverb. Adverb er de ordene som forteller om verbet: «Hussein gikk fort» eller «Aurora snakket høyt». I begge disse eksemplene fungerer de tilsynelatende som gode forklaringer - på hvordan Hussein gikk, og hvordan Aurora snakket. Men adverb har en tendens til å snike seg inn i setninger uten at vi helt har oversikt over hva de gjør der, og skaper sitt eget innhold.

La oss se på setningen «Mariana var veldig åpen om diagnosen sin». Her er adverbet «veldig» ment å si noe om graden av åpenhet. Men hvor nyttig er ordet? Mitt bilde er at det heller tilslører enn forklarer.

Hvis vi leser setningen én gang til, denne gangen uten adverbet, fremstår den som et sterkere utsagn. Da blir det åpenheten i seg selv, ikke «mengden åpenhet» som utgjør substansen i setningen.

Putter vi adverbet tilbake inn i setningen, ser vi at det ikke egentlig sier noe om Mariana, eller hva Mariana har sagt. Det sier noe om hvilken vurdering den som lyttet til Mariana, har gjort seg.

For en leser er forklaringen på hva det var som førte til en slik vurdering, viktigere enn vurderingen i seg selv. Den kan kanskje heller utdypes ved å legge til en setning (eller flere): «Hun sa at alle rundt henne visste om den.»

Min erfaring er at det særlig er mengdeadverbene som sniker seg inn i teksten på denne måten: mye, veldig, lite, ofte, i stor/liten grad, sjelden og så videre. De angir mengder på upresise måter og tilfører teksten uklarhet istedenfor klarhet.

Løsningen er kanskje å angi mengde mer presist: «Mariana snakket ofte om diagnosen sin» kan byttes ut med «Mariana snakket om diagnosen sin omtrent i annenhver terapitime, og daglig i lunsjen».

\section{Setningene - skriv kort og klart}

Et av de viktigste praktiske skriverådene er å bruke korte setninger. Korte setninger er lettere å lese. Dessuten må skriveren skjerpe sin egen tanke når de skal formuleres. Ett konkret tips til å korte ned setninger er å gjøre dette i reskrivingsfasen eller redigeringsfasen (mer om dem lenger ned). 
Det trenger ikke være noe stort problem at vi skriver lange og tunge setninger med flere meningsdannelser på rad og rekke, dersom vi påtar oss redigeringsjobben etter at setningene er nedskrevet. I en slik redigeringsfase kan det være lurt å lete opp alle gangene vi har skrevet «og» midt i en lang setning, og så sjekke om det er mulig å erstatte dette ordet med et punktum.

\section{三 «t av de viktigste praktiske skriverådene er å bruke korte setninger.»}

I den norske skrivemåten er det vanlig å ha subjekt og verbal tidlig i setningen. Det er bedre å skrive «Guttene gikk bortover stien og snakket sammen» enn «Gående bortover stien snakket guttene sammen». I det siste eksempelet må vi langt ut i setningen før vi finner subjektet, altså hvem setningen handler om.

Et mer faglig orientert eksempel er dette: «I denne diskusjonen har det blitt hevdet fra legehold at ...». Her blir legene usynliggjort som aktører, og setningen blir tung å lese. Da er det bedre å skrive «Legene har hevdet at ... i denne diskusjonen».

Det er dessuten best å gjøre subjektet klart og tydelig, slik jeg var inne på tidligere. Som regel vil det kunne gjøres ved å uttrykke setninger som springer ut fra tydelige første-, annen-, eller tredjepersonsrepresentasjoner - jeg, du, han/henne, de/dem. I stedet for «det hevdes» kan vi vise til hvem som hevder noe, for eksempel «sykepleierne hevder».

Et tredjepersonsord som misbrukes gjennom overforbruk, er «de». Dette ordet kan betegne mennesker, ting, hendelser og fenomener. Hvis dette ordet brukes ofte i en tekst, kan det være vanskelig for leseren å følge med på hva skriveren mener i det enkelte tilfellet.

\section{Avsnittene - strukturer teksten}

Ifølge King (3) er det ikke ordene eller setningene som er tekstens viktigste bestanddel. Det er avsnittene. Hvert avsnitt danner en meningsfull del av helheten. Det konstrueres av en indre logikk, og dersom dette gjøres bevisst, vil det hjelpe leseren til å sette seg inn i tekstens budskap. 
Det viktigste rådet King gir, er å begynne hvert avsnitt med en setning som gir hovedinnholdet i avsnittet. En definerende setning som tar leseren med inn i hva avsnittet handler om. De neste setningenes funksjon er å utdype dette innholdet.

En slik skrivemåte hjelper leseren til å ta inn avsnittets budskap etter en bestemt modell. Når (og hvis) leseren får Øye på at skriveren følger denne modellen, oppstår det en felles forståelse av hvordan skriverens tankerekke er konstruert. Det letter lesningen.

Når vi så skal gå videre til neste poeng i den teksten vi skriver, bør vi legge dette i neste avsnitt. Med dobbel linjeavstand mellom de to avsnittene blir det lettere for leseren å følge skriverens kjede av tanker. Den åpne linjen («luftrommet») mellom to avsnitt er også viktig for å gi leseren en liten pustepause.

\section{Lag gode overskrifter}

En god hjelper i fagskriving er titler, eller overskrifter, over de ulike kapitlene. De er viktige for leseren, fordi leseren får god hjelp til å forstå hva kapitlet skal handle om. Vel å merke hvis de er gjennomtenkte og godt bearbeidet. Og - og her kommer bonusen - de er også en god hjelp for skriveren. Gode titler hjelper skriveren til å holde hodet klart og følge en logikk i skrivearbeidet sitt.

La oss se nærmere på denne funksjonen. En skriver som setter opp titler for hvert kapittel, vil gi seg selv hele to verktøy til å sjekke ut sin egen tekst - i redigeringsfasen. Det ene er å bruke tittelen til å sjekke om kapitlet handler om det tittelen «lover».

Det andre er å sjekke om tittelen dekker det innholdet teksten danner. Ved å gå fra tittel til kapittel og tilbake igjen kan vi altså finne ut om de samsvarer. Når vi arbeider med dette og nærmer oss at de samsvarer, har vi sannsynligvis skapt en mer forståelig tekst - for leseren. Dessuten har vi antakelig også skapt bedre sammenheng i vår egen argumentasjon.

Titler kan også brukes som et «underveisverktøy». Vi kan sette opp så mange titler vi vil, underveis i skrivingen. Det kan bidra til at hvert eneste avsnitt får en klar indre struktur. 
Hvis vi bruker en slik skrivemåte, kan vi ta bort de titlene vi ikke trenger når vi kommer til redigeringsfasen. Dermed vil leseren aldri oppdage at de har vært der. Vi har bare brukt dem som en hjelp for oss selv mens vi arbeidet med teksten.

\section{Skriveprosessen - skriv i faser}

Selve prosessen med å skrive en tekst er en personlig prosess. Vi er ulike når det gjelder hvorvidt vi trives best med å skrive på den ene eller den andre måten. I fagskriving foretrekker noen å ha alt det aktuelle fagstoffet klart før selve skriveprosessen begynner - alle artikler og bøker om temaet skal være lest.

\section{三 «Det kan være lurt å bli kjent med sin egen arbeidsstil.»}

Andre arbeider ved å begynne å skrive tidlig, og heller lese seg opp på deltemaer underveis. Noen arbeider på en ryddig og strukturert måte, andre liker en friere stil. Det kan være lurt å bli kjent med sin egen arbeidsstil. Da kan vi rendyrke den. Men vi kan også øke vår egen skrivekompetanse ved å låne fra andre stiler når vi kjenner vår egen godt.

Ett generelt råd om skriveprosessen er mange erfarne skrivere enige om. Det dreier seg om å skrive i flere faser. King (3), Andersen (4) og Storø (5) foreslår en tofasemodell, som kan kalles skriving og re-skriving. Rognsaa (6) deler inn i tre faser; førskriving, skriving og redigering.

\section{Ikke glem å redigere}

Jeg vil særlig peke på re-skriving/redigering som en viktig fase og en viktig funksjon i skrivingen. Denne fasen gir håp til alle skrivere som synes de sliter med å få noe ned «på papiret», eller som ikke finner de gode formuleringene ved første fors $\varnothing \mathrm{k}$ : Vi kan alltid komme tilbake til teksten litt senere. Andersen (4, s. 510) beskriver dette slik:

«I virkeligheten består en stor del av skrivearbeidet ikke i selve skrivingen, men i redigeringen: Den langsomme og nødvendige prosessen det er å lese langsomt og grundig gjennom sin egen tekst, ord for ord, og så stryke, rette, flytte, ordne, rydde i teksten.» 
Ofte er det lurt å legge inn en pause mellom skrivefasen og re-skrivingsfasen. Om den så bare er på ett døgn. Men vi kan gjerne la den være lenger, for eksempel en uke. Da vil vi få «luftet ut» i hodet, kunne slappe av litt i strevet med gode formuleringer og letingen etter faglige sammenhenger.

Når vi så kommer tilbake til teksten, vil vi kunne se på den med nye øyne. Dessuten vil vi kanskje oppdage at vi har hatt den i tankene underveis, og at det har ført til ny innsikt om hva som vil ta den videre.

Re-skrivingsfasen kan tas i flere runder. Det er nesten ingen grenser for det forbedringspotensialet vi da kan hente ut av den første skrivefasens kladd. Det er gjerne i disse rundene den endelige kvaliteten i en tekst skapes.

\section{Avslutning}

Min målsetting med disse to artiklene har vært å gi en begrunnelse for å arbeide med formen i fagskriving og å gi konkrete tips til hvordan vi kan arbeide med den. Jeg har ønsket å bidra til at den sykepleiefaglige litteraturen formidles slik at den når sine lesere. Det vil kunne være med på å styrke faget og de som utøver det.

\section{Referanser}

1. Kittilsen L. Den smittsomme substantivsyken. Dagens Medisin. 02.10.2017. Tilgjengelig fra:

https://www.dagensmedisin.no/artikler/2017/10/02/densmittsomme-substantivsyken/ (nedlastet 07.08.2020).

2. Klarspråk. Svadagenerator. Helseadministrativ svada. Oslo: Språkrådet, Difi. Tilgjengelig fra:

http://svadagenerator.no/?type=Helseadministrativ+svada (nedlastet 07.08.2020).

3. $\quad$ King S. Om å skrive. - forfatteren og håndverket. Oslo: Aschehoug; 2002.

4. Andresen MM. Skriveboka. Oslo: Aschehoug; 2008.

5. Stor $\varnothing$ J. Du må skrive! Skrivebok for studenter i barnevern og sosialt arbeid. Oslo: Universitetsforlaget; 2019.

6. Rognsaa, Aa. Kunsten å skrive godt. Oslo: Tano Aschehoug; 1998. 